\title{
ZMIANY W WYMIARACH POLITYKI OCHRONY ZDROWIA
}

\author{
Justyna Kięczkowska \\ Uniwersytet Marii Curie-Skłodowskie w Lublinie \\ Wydział Politologii \\ e-mail: justyna.kieczkowska@poczta.umcs.lublin.pl
}

\begin{abstract}
Streszczenie: Celem artykułu jest ukazanie wymiarów polityki ochrony zdrowia - głównych celów koniecznych do realizacji przez podmioty odpowiedzialne w ramach tych wymiarów, a przede wszystkim zmian wprowadzanych reformą służby zdrowia rządu Prawa i Sprawiedliwości. Działania obecnego rządu w obszarze ochrony zdrowia jednoznacznie modyfikują system w kierunku Narodowej Służby Zdrowia, której wzór zaczerpnięto z Wielkiej Brytanii, gdzie model ten funkcjonuje od 1948 roku. Modyfikacje dokonywane w polskim systemie z założenia mają na celu usprawnić go, poprawić jego efektywność, a także stworzyć go bardziej przystępnym dla obywateli. Projektowane i wprowadzane przekształcenia sytemu ochrony zdrowia w Polsce, oparte w określonych wymiarach na reformie rządu, zaprowadzają system, który w perspektywie czasu ma realizować zasady powszechnego, niczym nieograniczonego dostępu do świadczeń zdrowotnych na jak najlepszym poziomie.
\end{abstract}

Słowa kluczowe: polityka ochrony zdrowia, system ochrony zdrowia, reforma sytemu ochrony zdrowia, Narodowa Służba Zdrowia

\section{WSTĘP}

Celem artykułu jest przedstawienie zmian w poszczególnych wymiarach polityki ochrony zdrowia, które są wynikiem reformy rządu Prawa i Sprawiedliwości, a które wprowadzają model Narodowej Służby Zdrowia. Działania te są zdeterminowane przede wszystkim oczekiwaniami społecznymi, które jednoznacznie wskazują na konieczność modyfikacji sytemu ochrony zdrowia. Rząd przyjął strategię, która zakłada całościową modyfikację sytemu ochrony zdrowia. Poszczególne jego obszary mają być objęte zmianami usprawniającymi dystrybucję świadczeń zdrowotnych, poprawiającymi mechanizm finansowania szpitali, usług, świadczeń, wprowadzającymi opiekę skoordynowaną, co w efekcie 
ma skutkować poprawą zdrowia publicznego obywateli, a tym samym odciążyć system ochrony zdrowia w państwie.

Narodowa Służba Zdrowia to model zaczerpnięty z Wielkiej Brytanii, gdzie system ochrony zdrowia funkcjonuje na podstawie zasad NHS od 1948 r. System NHS zasadza się na następujących filarach (aktualnych również obecnie): oddzielenie wypłat zasiłków chorobowych od leczenia, powszechność i szeroki zakres bezpłatnych świadczeń medycznych dla wszystkich rezydentów niezależnie od osiąganych dochodów i stanu zdrowia, finansowanie ochrony zdrowia ze źródeł publicznych (podatków), co oznacza wprowadzenie tzw. zaopatrzeniowego (budżetowego) w odróżnieniu od składkowego systemu finansowania, równość dostępu do świadczeń zdrowotnych, wprowadzenie trójszczeblowego systemu administrowania NHS [Ortyl 2004]. W przypadku Polski wprowadzenie zasady Narodowej Służby Zdrowia dotyczy głównych obszarów, które od 1989 r. nie mogą pozbyć się elementów dysfunkcjonalności. Zmiany obejmą więc: system zarząadzania i finansowania opieki zdrowotnej, organizację leczenia szpitalnego, podstawową opiekę zdrowotną, zdrowie publiczne [Sielicki 2016]. Dla celu ich realizacji obecny rząd wyznaczył pięć priorytetów koniecznych do wdrożenia w celu eliminacji dysfunkcji na poziomie sytemu ochrony zdrowia, a mianowicie: budowę sprawnego sytemu zarządzania powszechnie dostępnej służby zdrowia, wprowadzenie sieci szpitali, zwiększenie nakładów na służbę zdrowia, wdrożenie nowej podstawowej opieki zdrowotnej, utworzenie Urzędu Zdrowia Publicznego [Monitor Zmian w Systemie Ochrony Zdrowia, 2017]. Wytycznym tym podporządkowano cele szczegółowe, które dopełniają mechanizm reformy i wskazują na elementy wymagające poprawy i usprawnienia. Założenia te można i należałoby również połączyć z wymiarami polityki ochrony zdrowia, wpisać je w główne, zasadnicze kwestie związane z realizacją celów na ich poziomie, co pozwoliłoby na stworzenie i wdrożenie mechanizmu wydolnego i efektywnego systemu ochrony zdrowia.

\section{ASPEKT TEORETYCZNY: POLITYKA OCHRONY ZDROWIA I SYSTEM OCHRONY ZDROWIA}

Najnowsze ujęcia polityki zdrowotnej opierają się na stwierdzeniach dotyczących planu działania właściwego dla władz państwowych czy organizacji społecznych, który to plan ma służyć rozwiązywaniu problemów zdrowotnych i ma być realizowany z pomocą dostępnych zasobów i odpowiedniego zaplecza naukowego [Włodarczyk 2001]. Takie określanie polityki zdrowotnej wskazuje co prawda na formę współpracy na szczeblu rządowo-społecznym w kwestiach rozwiązywania problemów zdrowotnych. Zaznacza, iż opiera się ona na tworzeniu racjonalnych programów na podstawie podziału zarówno zasobów finansowych, jak i merytorycznych. Sprowadza jednak działania w zakresie polityki zdrowotnej jedynie do strategii służących problemom zdrowotnym, a nie szeroko pojętego zdrowia całego społeczeństwa. 
Zasadne więc wydaje się skonstruowanie definicji łączącej zarówno szerokie ujęcie polityki zdrowotnej, rozumianej jako tworzenie podstawowych ram jej funkcjonowania, obowiązujących w długim przedziale czasu, ze szczególnym uwzględnieniem podziału odpowiedzialności między obywateli i państwo za zdrowie i dostęp do opieki zdrowotnej i będące jego rozwinięciem, podstawowe reguły organizacyjne, jak i wąskie ujęcie definiujące politykę zdrowotną jako zadania bieżące, wśród których szczególną rolę odgrywa ustalenie wielkości środków przeznaczonych na zdrowie [Włodarczyk 2001]. Konstruując taką definicję, oprócz uwzględniania władczego, decyzyjnego charakteru polityki zdrowotnej, kwestii operacyjnych rozwiązań o ograniczonych skutkach należy brać pod uwagę inne konieczne czynniki, takie jak:

- czynnik ekonomiczny - wynikający z ogólnej sytuacji ekonomicznej i gospodarczej kraju, zamożności i poziomu życia społeczeństwa,

- czynnik społeczny - czyli ogólną sytuację demograficzną, tendencje rozwoju ludności, świadomość zdrowotną społeczeństwa, działalność organizacji pozarządowych,

- czynnik polityczny - obrazujący, jakie miejsce zajmuje ochrona zdrowia w programach partii politycznych, pracach organów rządowych,

- czynnik środowiskowy - ukazujący realny stan środowiska oraz mogące wystąpić zagrożenia spowodowane jego zanieczyszczeniem, degradacją.

Uwzględnianie tych czynników jest konieczne i właściwe podczas tworzenia definicji polityki zdrowotnej. Budowanie założeń i działań tej polityki w związku z jej charakterem nie może być bowiem pozbawione wpływów z rzeczywistości politycznej i społecznej. Poszerzając definicję minimum polityki zdrowotnej (rozumianej jako proces polityczny - fragment procesu - mający związek ze zdrowiem) [Włodarczyk 2014] o elementy definicji polityki i zdrowia, autor stwierdził, iż „polityka ochrony zdrowia to ogół działań podjętych przez ośrodki decyzyjne mających na celu uzyskanie i trwałe zapewnienie zdrowia fizycznego i psychicznego obywateli, a także powszechnego dostępu do sytemu opieki zdrowotnej, jak i prawidłowego i efektywnego funkcjonowania tegoż systemu za pomocą środków właściwych dla organów i instytucji o charakterze rządowym, samorządowym i społecznym".

Definicja taka wskazuje także na możliwość modyfikacji działań w ramach polityki ochrony zdrowia w zależność od instytucji, która takie aktywności podejmuje. Inaczej bowiem będzie przedstawiała się polityka ochrony zdrowia prowadzona w Ministerstwie Zdrowia, odmienne czynniki będą priorytetowe dla działań organizacji pozarządowych czy lokalnych. Definicja ta zawiera również przesłankę umożliwiającą kreowanie ogólnego modelu polityki zdrowotnej przez działania samych obywateli.

Zmiany wprowadzane w systemie ochrony zdrowia, rozumianym jako zbiór elementów współdziałających ze sobą, mających na siebie wpływ i wzajemnie się warunkujących, są przejawem realizacji określonych założeń w ramach polityki ochrony zdrowia. W przypadku modelu Narodowej Służby Zdrowia należy 
w sposób szczególny zwrócić uwagę na wymienione czynniki, konieczne do uwzględnienia w ramach wprowadzonych przekształceń. Aspekt ekonomiczny, społeczny, środowiskowy czy polityczny ma bowiem istotne znaczenie dla podmiotów realizujących zmianę, jak również korzystających z jej efektów. Analizując sam proces wprowadzania reformy systemu ochrony zdrowia rządu PiS, można dostrzec, iż z złożenia ma ona charakter kompleksowy. Poczynając od przekształceń instytucjonalnych, przez zmiany kompetencyjne, finansowe, na modyfikacjach dotyczących bezpośrednio świadczeniobiorców skończywszy. Należy również podkreślić, że jest to także kolejna reforma, która zakłada bardzo ogólne założenia bez wskazania mechanizmów czy czynników koniecznych do uwzględnienia w celu jej realizacji.

\section{WYMIARY POLITYKI OCHRONY ZDROWIA - ZMIANY REALIZUJĄCE CELE W ICH OBSZARZE}

Analizując politykę zdrowotną jako działanie służące ochronie zdrowia, a także jako część procesu politycznego, można sformułować katalog jej głównych celów odnoszących się do poszczególnych wymiarów życia społecznego i działalności politycznej. Tworząc katalog głównych celów polityki zdrowotnej, należy więc przyjąć konkretne wymiary, według których należy je wyznaczyć. Jednym z nich jest wymiar społeczny - w jego ramach można przedstawić następujące cele polityki zdrowotnej:

- eliminacje czynników pogarszających stan zdrowia społeczeństwa,

- powszechny dostęp do opieki zdrowotnej,

- powszechny udział w edukacji zdrowotnej i wszystkich rodzajach profilaktyki,

- poszanowanie godności i praw pacjenta,

- poszanowanie uprawnień i godności lekarzy (w tym uregulowanie kwestii dotyczących statusu zawodu lekarza).

Wyznaczenie szczegółowych założeń w ramach celów wymiaru społecznego ma bazować przede wszystkim na ciągłym monitorowaniu, nadzorowaniu stanu zdrowia społeczeństwa, a także czynników wpływających na rozwój zagrożeń dla zdrowia. W ramach tego wymiaru czekają na realizację założenia nowej reformy rządowej wprowadzającej Narodową Służbę Zdrowia w ramach priorytetu IV Nowa Podstawowa Opieka Zdrowotna. Główną zmianą ma być więc utworzenie efektywnej opieki zdrowotnej na poziomie podstawowym. Do tego celu mają być utworzone zespoły Podstawowej Opieki Zdrowotnej (POZ), w skład których wchodziłby lekarz, pielęgniarka, położna, pielęgniarka szkolna oraz dietetyk (Ustawa o podstawowej opiece zdrowotnej). Jednym z priorytetowych zadań takiego zespołu - według założeń nowej reformy - ma być współpraca ze szkołami, przedszkolami i innymi podmiotami, w tym lekarzami, związana z profilaktyką zdrowia pacjenta (Narodowa Służba Zdrowia). Sama idea jawi się 
wspaniale, dołączając do niej mechanizm związany z powszechną dostępnością do lekarza pierwszego kontaktu, który ma być równocześnie koordynatorem opieki medycznej nad pacjentem. Na poziomie państwa zagwarantowanie powszechnej dostępności do podstawowej opieki zdrowotnej i procedur ratujących życie wszystkim obywatelom jest sprawą priorytetową. Koordynacyjna działalność POZ jest natomiast elementem zasadniczym w realizacji celów o charakterze profilaktycznym w wymiarze społecznym. Taki charakter i model opieki nad pacjentem spełnia swoją rolę jedynie wtedy, gdy wszystkie jego elementy funkcjonują sprawnie, a przede wszystkim są efektywne w ramach systemu opieki zdrowotnej [Sadurska 2017]. W obszarze wymiaru społecznego to właśnie Podstawowa Opieka Zdrowotna ma działać tak, aby unikać realnych zagrożeń dla życia i zdrowia pacjenta, a tym samym ograniczać przypadki hospitalizacji. Takie aktywności mają być realizowane w ramach POZ w kontekście szeroko rozumianej promocji zdrowia i edukacji zdrowotnej pacjentów, która ma się istotnie przyczyniać do poprawy stanu zdrowia, co jest równoznaczne ze zmniejszeniem liczby chorych i wizyt u specjalisty. Zachęty finansowe ze strony Ministerstwa Zdrowia mają stanowić mechanizm aktywizujący $\mathrm{POZ} \mathrm{w}$ działalności prozdrowotnej, a tym samym wpływać na ograniczenie kosztów związanych z leczeniem specjalistycznym (Monitor Zmian w Systemie Ochrony Zdrowia). Największym mankamentem tego założenia, jak również jego realizacji w ramach wymiaru społecznego polityki ochrony zdrowia jest fakt wciąż małej świadomości zdrowotnej obywateli, która stanowi barierę w realizacji i rozwoju skoordynowanej opieki zdrowotnej w ramach POZ. Nowe wyzwanie, jakie stawia przed zespołami POZ reforma, będą także realizowane, jeśli zadziała mechanizm współpracy na linii pacjent-POZ-specjalista-szpital. Cele zawarte w wymiarze społecznym powinny także określać pozycję lekarza w relacjach z pacjentem, nie tylko jako świadczeniodawcy, lecz przede wszystkim jako osoby wypełniającej zawód wysoce specjalistyczny i odpowiedzialny. Nowa reforma zakłada, iż to właśnie lekarz Podstawowej Opieki Zdrowotnej będzie „strażnikiem” pacjenta i jego zdrowia. Wzmocnienie pozycji lekarz POZ ma na celu usprawnienie ewentualnego procesu leczenia. Skoordynowane leczenie stawia lekarza i jednocześnie zespół POZ na pozycji głównego decydenta odpowiedzialnego za zdrowie pacjenta. Pacjent w ramach społecznego wymiaru celów polityki zdrowotnej powinien natomiast posiadać prawo do informacji, a także prawa do jak najlepszych warunków podczas korzystania z usług medycznych (Monitor Zmian w Systemie Ochrony Zdrowia). Nowa ustawa zakłada takie rozwiązania i możliwości, nie wskazując jednak konkretnych mechanizmów usprawniających czy też poprawiających dostęp do lekarza Podstawowej Opieki Zdrowotnej, sposobów uzyskania informacji i wiedzy przez pacjenta (od 2018 r. Narodowa Służba Zdrowia - kierunki reformy).

Należy więc stwierdzić, iż te rozwiązania ustawowe zakładają model systemu ochrony zdrowia charakteryzujący się powszechną dostępnością, jak również sprawną i niczym niezakłóconą współpracą na linii lekarz-pacjent. Można jednak zauważyć, iż oprócz założeń brakuje konkretnych wytycznych, elementów syte- 
mu, które uruchomią efektywny proces Podstawowej Opieki Zdrowotnej w wykonaniu zespołów POZ. Sama informacja o możliwościach i zmianach w systemie nie jest bowiem wystarczająca dla funkcjonowania poszczególnych podmiotów pełniących kluczową rolę w wymiarze społecznym polityki ochrony zdrowia.

Kolejnym wymiarem polityki ochrony zdrowia jest wymiar polityczny. Realizacja określonych celów w jego ramach jest kwestią nierozerwalnie związaną z charakterem politycznym i założeniami ideologicznymi ugrupowań rządzących w państwie. Obecna ekipa rządząca w swoim programie związanym z ochroną zdrowia duży nacisk kładzie przede wszystkim na poprawę dostępności i funkcjonowania podmiotów specjalistycznych o kluczowym znaczeniu dla sytemu, tj. szpitali.

Do głównych celów w wymiarze politycznym w ramach polityki ochrony zdrowia w ujęciu ogólnym należy zaliczyć:

- określenie głównych założeń polityki zdrowotnej o charakterze długofalowym,

- wprowadzenie jasnych i efektywnych zasad finansowania działań poszczególnych podmiotów systemu ochrony zdrowia o charakterze specjalistycznym (szpitali, przychodni),

- stworzenie przejrzystego podziału obowiązków, a tym samym odpowiedzialności za politykę zdrowotną na poziomie ministerialnym i specjalistycznym.

Nowa reforma systemu ochrony zdrowia, jak również polityczne założenia programowe rządu premier Beaty Szydło zakładały usprawnienie i poprawę wydolności systemu w perspektywie kilkunastu lat. Przejawem działań usprawniających jest ustawa o sieci szpitali, której bezpośrednim skutkiem ma być poprawa udzielania świadczeń opieki zdrowotnej przez szpitale czy przychodnie przyszpitalne, jak również poprawa dostępu pacjentów do leczenia specjalistycznego w szpitalach [Sieć Szpitali 2017]. Bezpieczny system szpitalny wprowadzony ustawą o sieci szpitali zakłada: uporządkowanie struktury szpitalnictwa (system podstawowego zabezpieczenia szpitalnego wprowadza trzy podstawowe i cztery specjalistyczne poziomy sieci szpitali), gwarancje stabilnego finansowania (szpital uzyska gwarancje finansowania przez 4 lata, oparte na okresowych ryczałtach, uzależnionych od efektywności szpitala), konkursy dla szpitali i zakresów spoza sieci (co ma skutkować tym, że żaden szpital nie zostanie zlikwidowany), elastyczne zarządzanie szpitalnym budżetem (co ma poprawiać sytuację finansową szpitali) [Sieć Szpitali 2017]. Wszystkie szpitale, które wykażą, iż spełniają kryteria kwalifikacyjne określone w ustawie i rozporządzeniach, wejdą do tzw. Systemu podstawowego szpitalnego zabezpieczenia świadczeń opieki zdrowotnej (PSZ) [Konieczny 2017]. System ten będzie w 91\% finansowany z środków, z których obecnie jest finansowane leczenie szpitalne. Spełnienie kryteriów kwalifikacyjnych i włączenie szpitala do systemu PSZ ma być równoznaczne z zawarciem umowy z Narodowym Funduszem Zdrowia bez konieczności przeprowadzania procedury konkursowej [W życie wchodzi sieć szpitali, 2017]. 
Już samo określenie ,sieć” ma sprawiać wrażenie, iż pacjent ma możliwość skorzystania z opieki zdrowotnej o charakterze ciągłym i skoordynowanym, co jednoznacznie ma wskazywać na fakt, że w tak funkcjonujących szpitalach osoba chora uzyska pełen wachlarz usług medycznych, i co więcej, odbywać się to będzie bez szczególnych utrudnień. Główne założenie tej zmiany ma jednak przede wszystkim rozwiązać kluczowe problemy podmiotów specjalistycznych związane z finansowaniem świadczeń zdrowotnych [Majewska 2017]. W założeniach ustawy o sieci szpitali mowa jest o konieczności poprawy relacji pomiędzy płatnikiem, czyli NFZ i wykonawcami świadczeń, zagwarantowaniu ciągłości i stabilności finansowania jednostkom istotnym z punktu widzenia zabezpieczenia dostępu do świadczeń zdrowotnych przy równoczesnym pozostawieniu możliwości dostępu do środków publicznych pozostałym jednostkom, uelastycznieniu zarządzania szpitalem oraz optymalizacji struktury kosztów leczenia. Szpital zakwalifikowany do sieci po weryfikacji przez dyrektora oddziału wojewódzkiego NFZ w zakresie świadczeń wskazanych w kwalifikacji uzyska tym samym prawo do umowy z NFZ z pominięciem trybu konkursowego na okres 4 lat [Ustawa o Sieci szpitali..., 2017]. Samo rozliczanie kosztów świadczeń na podstawie umów zawartych $\mathrm{w}$ ramach sieci szpitali będzie się odbywać w formie ryczałtowej, a wysokość ryczałtu będzie uzależniona od liczby i struktury świadczeń udzielonych i sprawozdanych przez podmiot świadczący w poprzednich okresach [Rek, Klimczak-Wieczorek 2017]. Tego typu rozwiązanie może dawać optymistyczną perspektywę, iż ośrodki specjalistyczne wykazujące dużą aktywność w świadczeniu usług medycznych będą miały stabilną sytuację finansową i tym samym będą w stanie spełnić oczekiwania pacjentów wobec usług, jakie mają być zapewnione w ramach sieci szpitali. Globalny ryczałt (takie określenie pojawia się w projekcie ustawy) będzie więc wymagał od szpitali efektywnego zarządzania i dzielenia go na odpowiednie procedury i świadczenia [Majewska 2017]. Rozwiązanie to ma również wyeliminować niską efektywność ekonomiczną w procesie leczenia i opieki nad pacjentem, zbędne i przedłużające się hospitalizacje i ich celowe przedłużanie. W sieci szpitali, finansowanej w ramach ryczałtu większa część budżetu ma być przeznaczana celowo na świadczenia opieki zdrowotnej [Panek 2017].

W wymiarze politycznym istotną kwestią jest również podział kompetencji, a raczej ich precyzyjne określenie na poziomie podmiotów o charakterze państwowym. Założenia programowe i działania polityczne obecnej ekipy rządowej jednoznacznie wskazują na konieczność rozwiązania sporów kompetencyjnych zwłaszcza na linii Ministerstwo Zdrowia-Narodowy Fundusz Zdrowia. Lekiem na ten problem ma być likwidacja Narodowego Funduszu Zdrowia, który to proces miał się rozpocząć od stycznia 2018 r. [Greń 2017]. Od tego czasu kompetencje NFZ miało przejąć Ministerstwo Zdrowia. To rozwiązanie z założenia wydawało się zabiegiem usprawniającym, a przede wszystkim eliminującym instytucje, której odpowiedzialności politycznej i społecznej nikt do końca nie był pewien i której uprawnienia $\mathrm{w}$ większości pokrywały się z uprawnieniami 
Ministerstwa Zdrowia [Kurowska 2017]. Przeniesienie odpowiedzialności na podmiot stricte rządowy może w perspektywie oznaczać pełną odpowiedzialność państwa za dostępność i realizację powszechnej dostępności do ochrony zdrowia obywateli. Działania eliminujące spory kompetencyjne i poprawiające tym samym efektywność całego systemu mają również dotyczyć poziomu lokalnego [Radziwiłł 2017]. Wraz z likwidacją Narodowego Funduszu Zdrowia, a tym samym jego wojewódzkich oddziałów mają powstać Wojewódzkie Urzędy Zdrowia, których głównym zadaniem będzie rozliczanie świadczeń [Gzell 2017]. Teraz już wiadomo, iż do likwidacji NFZ nie dojdzie, a przynajmniej nie w tej kadencji i że był to postulat jedynie polityczny [Klingier 2017]. Obecny rząd PiS wskazuje również na fakt, iż w związku z dobrą koniunkturą gospodarczą nie ma potrzeby przechodzić na budżetowy system finansowania ochrony zdrowia, a tym samym wprowadzać zmian instytucjonalnych związanych z mechanizmem finansowania systemu [Wróbel 2018].

Ogół zmian wprowadzanych przez rząd PiS, dotyczących podziału kompetencji, ich szczegółowego określenia, wskazuje na fakt wdrażania założeń programowych zmieniających system ochrony zdrowia w państwie z ubezpieczeniowego na narodowy. Większość zadań przejawiających się w promocji zdrowia, edukacji zdrowotnej, organizacji specjalistycznego sytemu opieki zdrowotnej ma się stawać domeną państwa i podmiotów rządowych. Obecne władze stoją na twardym stanowisku konieczności realizacji konstytucyjnego prawa obywateli do powszechnego i niczym nieograniczonego dostępu do ochrony zdrowia i w ich ujęciu realizacja tego założenia jest możliwa jedynie na podstawie narodowego systemu i sieci szpitali. Pozytywnym aspektem tych zmian jest fakt, iż zakładają one optymalizację działań w ramach finansowania i funkcjonowania podmiotów specjalistycznych, a przede wszystkim poprawę bezpieczeństwa zdrowotnego obywateli, zwłaszcza przez upowszechnienie dostępu do systemu opieki zdrowotnej i nadanie jej skoordynowanego charakteru. Można więc zauważyć, że założenia programowe, jak również sama reforma wprowadzająca sieć szpitali ma usprawnić i poprawić efektywność funkcjonowania instytucji specjalistycznych w ramach sytemu ochrony zdrowia. Podkreślenia wymaga również fakt, iż zakładane zmiany są związane zarówno ze stopniowym wzrostem nakładów na ochronę zdrowia w państwie, jak i na wynagrodzenia osób wykonujących zawody medyczne. Perspektywa uzyskania zadowalającego poziomu wpływów do systemu ochrony zdrowia jest w założeniach rządu odległa, bo aż do roku 2025, może jednak wskazywać, że wprowadzane zmiany mają za zadanie rzeczywistą i realną poprawę funkcjonowania sytemu i wszystkich jego elementów.

Cele w wymiarze politycznym powinny być oparte na jasnych intencjach przejawiających się zarówno na poziomie prawodawstwa, jak i działania politycznego. Założenia i ustawa o sieci szpitali autorstwa rządu PiS są planem naprawczym dla ubezpieczeniowego sytemu ochrony zdrowia funkcjonującego w Polsce, wprowadzającym system narodowej ochrony zdrowia w całości oparty na finansowaniu z budżetu państwa i kontroli ze strony Ministerstwa Zdrowia. 
Z płaszczyzny świadczeniobiorcy - pacjenta - wprowadzane zmiany jawią się jako system funkcjonujący na rzecz i w jego interesie. Pozostaje zadać pytanie o zasady funkcjonowania nowych mechanizmów sytemu ochrony zdrowia, sposób współdziałania poszczególnych elementów, takich jak np. pacjent - zespół podstawowej opieki zdrowotnej, czy pacjent - zespół szpitala sieciowego? W samej ustawie i założeniach dotyczących systemu ochrony zdrowia autorstwa rządu PiS brakuje jasnych i jednoznacznych odpowiedzi. Niepokój budzą też zasady finansowania, które przy założeniu, iż 91\% zostanie przekierowane do sieci, wskazują, że $9 \%$ pozostanie na resztę usług, co ewidentnie ograniczy wykonywanie np. procedur jednodniowych. Obawy środowisk lekarskich są naturalne i zrozumiałe, kolejne zmiany stają się faktem, a ich efektywność czy też dysfunkcyjność zostanie wykazana w trakcie realizacji, niestety najczęściej na organizmach pacjentów.

Kolejnym i jednym z najważniejszych wymiarów w płaszczyźnie polityki ochrony zdrowia jest wymiar infrastrukturalny. W odniesieniu do dwóch poprzednich wymiarów to właśnie infrastruktura daje możliwość realizacji założeń w wymiarze społecznym i ukazanie efektywnych działań w wymiarze politycznym. Należy przyjąć, iż główne cele w wymiarze infrastrukturalnym to:

- rozbudowa i unowocześnianie zaplecza lokalowego instytucji ochrony zdrowia,

- wdrażanie nowych systemów informatycznych służących usprawnieniu zarządzania dokumentacją medyczną,

- prowadzanie nowych technologii polepszających diagnostykę i działania medyczne.

Analizując przykład Polski, widać wyraźnie zmiany i realizację celów związanych z modernizacją zaplecza lokalowego. Większość szpitali w dużych miastach to placówki nowoczesne, wyposażone w najnowocześniejszą aparaturę pozwalającą przeprowadzić zaawansowaną diagnostykę i procesy lecznicze na najwyższym poziomie. Wprowadzanie nowych technologii i procedur jest również związane z rozwojem współpracy międzynarodowej placówek świadczących usługi medyczne. Wszystko to prowadzi do zdecydowanego wzrostu jakości i profesjonalizacji usług medycznych. Dodatkowym elementem usprawniającym funkcjonowanie placówek medycznych są nowoczesne systemy informatyczne, które na obecną chwilę oprócz podstawowych informacji o pacjencie (e-WUŚ) mają służyć szybkiemu przekazywaniu niezbędnych danych dotyczących np. historii choroby. Profesjonalizacja i unowocześnienie służy przede wszystkim poprawie poziomu bezpieczeństwa zdrowotnego obywateli, którzy uzyskują wiedzę, iż system ochrony zdrowia działa na podstawie najwyższych standardów.

Ostatni z wymiarów i cele zawarte w nim stanowią swoistą klamrę zamykającą istotę i podstawy funkcjonowania systemu ochrony zdrowia i działań poszczególnych podmiotów w ramach polityk ochrony zdrowia. Wymiar międzynarodowy stanowi także pewnego rodzaju wyzwanie dla elementów systemu ochrony zdrowia. To bowiem w jego ramach można wyznaczyć następujące cele: 
- wyrównywanie poziomu zdrowia obywateli i służby zdrowia do poziomu europejskiego,

- angażowanie i podejmowanie programów służących prozdrowotnym zachowaniom,

- przyjmowanie międzynarodowych standardów w dziedzinie opieki zdrowotnej,

- udział w tworzeniu zasad transgenicznej opieki medycznej.

Międzynarodowe cele polityki zdrowotnej powinny niwelować obawy społeczne dotyczące korzystania i refundowania świadczeń w państwie i poza jego granicami. Realizacja zawartych w tym wymiarze celów powinna także zmniejszać dystans w świadczeniu i dostępności opieki zdrowotnej w samym poziomie zdrowia między Polską a państwami europejskimi. Dorównanie do europejskiego poziomu ochrony zdrowia jest możliwe jedynie przez zwiększenie wydatków na ochronę zdrowia, tymczasem w Polsce wydatki te stanowią $6,8 \%$ dochodu narodowego, z czego $4 \%$ to wydatki publiczne, gdzie w państwach UE średnia to $8,7 \%$. Najwięcej, bo ponad $10 \%$ PKB wydają tradycyjnie zamożne kraje tzw. starej Unii - Holandia, Francja, Niemcy czy Dania. Wprowadzenie modelu narodowego opartego na powszechnej dostępności nie wpłynie na lepszy poziom efektywności systemu w Polsce, a już na pewno nie zbliży go do standardów europejskich [Planowane wydatki na zdrowie, 2017]. Bez realnych wpływów i nakładów na ochronę zdrowia nie można zakładać najmniejszego nawet skoku jakościowego, czy to z punktu widzenia pacjenta, czy podmiotu świadczącego usługi medyczne. Polska jako państwo członkowskie Unii Europejskiej realizuje natomiast w pełni zasady zawarte w dyrektywie Parlamentu Europejskiego i Rady 2011/24/UE z dnia 9 marca 2011 r. w sprawie stosowania praw pacjentów w transgranicznej opiece zdrowotnej [Dyrektywa Parlamentu Europejskiego, 2011], co oznacza możliwość świadczenia opieki zdrowotnej lub przepisanego w państwie członkowskim innym niż państwo członkowskie ubezpieczenia. Cele w ramach wymiaru międzynarodowego zakładają także poprawę bezpieczeństwa obywateli z uwzględnieniem wszystkich aspektów życia społecznego, jak również specyfiki samego społeczeństwa, starzejącego się jak w przypadku Polski i większości państw Europy Zachodniej. Rozwój i wdrażanie programów prozdrowotnych, nastawienie na edukację i promocję zdrowia ma sprawić, iż społeczeństwo zachowa dobry stan zdrowia do późnej starości.

\section{WNIOSKI}

Wyznaczenie wymiarów, w ramach których można określić cele polityki zdrowotnej, daje możliwość konstruowania programów operacyjnych dla państwa i instytucji zarówno o charakterze państwowym, jak i pozapaństwowym w ramach działań na rzecz zdrowia. Takie uchwycenie celów skutkuje także wskazaniem na zasadnicze kwestie służące przede wszystkim usprawnieniu działalności na 
niwie polityki zdrowotnej i funkcjonowania służby zdrowia jako podstawowego świadczeniodawcy, a także na rzecz zachowań prozdrowotnych w społeczeństwie.

Wielowymiarowość celów podkreśla równocześnie mnogość problemów, z jakimi boryka się polityka zdrowotna. Pominięcie jednego z wymiarów w tworzeniu i realizacji polityki zdrowotnej skutkuje powstaniem sytuacji niekorzystnych dla szeroko pojętych świadczeniodawców, jak również wszystkich obywateli. Precyzowanie celów polityki zdrowotnej w określonych wymiarach stwarza także możliwość rozbudowanego dyskursu dotyczącego rozwoju polityki zdrowotnej i jej podstawowych zadań zarówno na poziomie rządowym, jak i społecznym. Zmiany w wymiarach polityki ochrony zdrowia w obecnej rzeczywistości częściowo pokrywają się z wyznaczonymi celami. Wprowadzane są one dość szybko, jednak bez wnikliwych analiz całego mechanizmu właściwego dla funkcjonowania systemu ochrony zdrowia w Polsce. Bardzo często są one wynikiem funkcjonowania specyficznych relacji rządzący-rządzeni, gdzie rządzący niejako odczytują prawdopodobne oczekiwania społeczne i starają się je realizować, co jest zauważalne w przypadku rządu PiS. Wdrażane zmiany są więc efektem analiz społecznych nastrojów wyborców, stąd powszechny dostęp do opieki zdrowotnej, zniesienie konieczności posiadania ubezpieczenia, lepszy dostęp do specjalistów i kompleksowa opieka już na poziomie podstawowym, a nie problemów systemu ochrony jako całości. W efekcie czego pojawia się coraz więcej głosów niezadowolenia ze strony podmiotów specjalistycznych, wyrażających się chociażby w strajkach pielęgniarek i położnych czy też lekarzy rezydentów. Reforma wygląda natomiast niezwykle imponująco i optymistycznie z punktu widzenia pacjenta. Niepokój budzą jednak liczne niewiadome zwłaszcza środowisk medycznych dotyczące jasnych zasad funkcjonowania czy mechanizmów wdrażania zapowiedzianych zmian. Można mieć jedynie nadzieję, iż wszyscy zainteresowani wykażą chęć współdziałania w ramach wprowadzanych zmian w myśl powszechnie znanej medycznej maksymy: ,po pierwsze nie szkodzić”.

\title{
Tytul: Changes in the Aspects of Health Care Policy
}

\begin{abstract}
The aim of the article is to show the aspects of health care policy, the main aims necessary for the entities corresponding to these aspects and, above all, the changes introduced by the reform of health service adopted by the Law and Justice government. The activities of the current government in the area of health protection clearly modify the system towards the National Health Service, whose model originates from Great Britain, where it has been in operation since 1948. The modifications introduced in the Polish system are aimed to streamline it, improve its effectiveness and accessibility for citizens. Designed and implemented transformations of the health care system in Poland, based on specific aspects as a result of government reform, introduce a system that in the long run will implement the principles of universal, unrestricted access to health services at the best possible level.
\end{abstract}

Keywords: health care policy, health care system, reform of health care system, National Health Service 


\section{BIBLIOGRAFIA}

1. Dyrektywa Parlamentu Europejskiego i Rady 2011/24/UE z dnia 9 marca 2011 r. w sprawie stosowania praw pacjentów w transgranicznej opiece zdrowotnej, https:/eur-lex.europa.eu/ legal-content/PL/TXT/?uri=celex:32011L0024 (dostęp: 24.04.2018).

2. Gzell T., 2017, Likwidacja NFZ prawdopodobna już nie w tej kadencji, „Do Rzeczy” 15.10.

3. Kaczmarczyk D., 2016, Narodowa Stużba Zdrowia, kierunki reformy, Kraków.

4. Klinger K., PiS wycofuje się z likwidacji NFZ. Przynajmniej na razie, http://serwisy.gazetaprawna.pl/zdrowie/artykuly/1055251,nfz-pis-likwidacja-zdrowie.html (dostęp: 25.04.2018).

5. Konieczny D., Ustawa o sieci szpitali ogłoszona w Dzienniku Ustaw, https://www.zdrowie.abc. com.pl/zmiany-w-prawie/ustawa-o-sieci-szpitali-zostala-ogloszona-w-dzienniku-ustaw, 110553. html (dostęp: 23.04.2018).

6. Konstytucja Rzeczypospolitej Polskiej z dnia 2 kwietnia 1997 r., Dz.U. 1997, nr 78, poz. 483.

7. Kurowska A., Reforma stużby zdrowia od 2018: Zniknie NFZ, a lekarz przyjmie każdego, http:// serwisy.gazetaprawna.pl/zdrowie/artykuly/1012857,reforma-sluzby-zdrowia-201-likwidacja-nfz.html (dostęp: 25.04.2018).

8. Majewska D., 2017, Minister Zdrowia o sieci szpitali: koniec z podziatem na lepszych i gorszych pacjentów, Warszawa.

9. Monitor Zmian w Systemie Ochrony Zdrowia, http://zmianywzdrowiu.pl (dostęp: 20.04.2017).

10. Narodowa Służba Zdrowia, http://www.mz.gov.pl/wp-content/uploads/2016/07/narodowa -sluzba-zdrowia-bez-dat.pdf (dostęp: 25.04.2018).

11. Ortyl G., 2004, System ochrony zdrowia w Wielkiej Brytanii, „Skalpel”, nr 4.

12. Panek J., Sieć szpitali: co przyniesie reforma PiS? Wyjaśniamy krok po kroku, www.wiadomosci. gazeta.pl (dostęp: 23.04.2018).

13. Planowane wydatki na zdrowie, www.pte.pl/pliki/1/282/planowanewydatkinazdrowiewlatach2017_2020.pdf (dostęp: 23.04.2018).

14. Radziwitt: Likwidacja NFZ przesadzona, http://www.medexpress.pl/radziwill-likwidacja-nfz -przesadzona/67361 (dostęp: 24.04.2018).

15. Sadurska A., Ministra Radziwilta pomysty na zdrowie. Oceniane okiem lekarza i pacjenta, http:// www.medonet.pl/zdrowie/zdrowie-dla-kazdego,narodowy-program-zdrowia-reforma-konstantego-radziwilla-ministra-zdrowia, artykul,1722144.html (dostęp: 23.04.2018).

16. Sieć Szpitali, http://siecszpitali.mz.gov.pl (dostęp: 23.04.2018).

17. Siedlicki P., 2016, Narodowa Stużba Zdrowia - strategia zmian w systemie ochrony zdrowia $w$ Polsce, Warszawa.

18. Ustawa o Sieci szpitali weszła $w$ życie, „Gazeta Lekarska”, http://gazetalekarska.pl/?p=33494 (dostęp: 24.04.2018).

19. Ustawa z dnia 27 października 2017 r. o podstawowej opiece zdrowotnej, Dz.U. 2017, poz. 2217.

20. Włodarczyk C., Paździoch S., 2001, Systemy zdrowotne: zarys problematyki, Kraków.

21. Włodarczyk C., 2014, Wspótczesna polityka zdrowotna. Wybrane zagadnienia, Warszawa.

22. Wróbel P., W NFZ odbywaja się pozytywne zmiany. Na razie likwidacji nie będzie, www.rynekaptek.pl (dostęp: 23.04.2018). 